\title{
Integrated Multitrophic Aquaculture: Filter Feeders Bivalves as Efficient Reducers of Wastes Derived from Coastal Aquaculture Assessed with Stable Isotope Analyses
}

\author{
Salud Deudero ${ }^{1}$, Ariadna Tor ${ }^{1}$, Carme Alomar ${ }^{1}$, \\ José Maria Valencia ${ }^{2}$, Piluca Sarriera ${ }^{1}$ and Andreu Blanco ${ }^{3}$ \\ ${ }^{1}$ Centro Oceanográfico de Baleares, Instituto Español de Oceanografia, Palma \\ ${ }^{2}$ Laboratorio de Investigaciones Marinas y Acuicultura, Andratx \\ ${ }^{3}$ Instituto de Investigaciones Marinas de Vigo, CSIC, Vigo \\ Spain
}

\section{Introduction}

Aquaculture industry has rapidly increased from 20 million tons in the 1990s to 68.4 million tons in 2008, overcoming the 67.0 million tons of extractive fisheries, with an approximated global value of 84,791 million Euros (FAO, 2010). The Mediterranean Sea is an important producer of intensive open water fish culture, especially important are industries from Spain, France, Italy and Greece, which generated 2,133 million Euros in 2008 (FAO, 2008).

Parallel to aquaculture industry development, knowledge of its effects on the surrounding environment is increasing. Several studies have been conducted to assess the environmental impact (Holmer et al., 2008; Yokoyama et al., 2006; Vizzini \& Mazzola, 2004) due to aquaculture. Organic enrichment is recognized as the most important problem associated to marine aquaculture (Mirto et al., 2010; Troell et al., 2003) as a direct result of the release of dissolved and particulate nutrient loads, especially organic phosphorous and nitrogen in the form of ammonia that might easily induce eutrophication (Karakassis et al., 2000). Uneaten pellet and fresh food supplied at fish cages, together with the excretion products from cultured fishes are the source of the nutrient loads released (Cheshuk et al., 2003).

Whereas the dissolved compounds are easily dispersed and diluted in the water column, the particulate compounds sink to the sea floor, causing severe modifications of the physical and chemical characteristics of the sediment and the community dynamics of marine seagrass and benthic fauna (Brown et al., 1987; Karakassis et al., 2000; Mente et al., 2006). The severity and extend of the environmental impact depends on a large number of factors, such as local hydrodynamics, water depth and total output from fish farms. Nevertheless, it has been detected organic enrichment in the sediment up to $1000 \mathrm{~m}$ from fish cages (Sarà et al., 2004).

The effects of the organic enrichment are widely studied in the Atlantic and the Pacific Ocean, especially in relation to the salmon industry (Brown et al., 1987; Cheshuk et al., 2003; 
Weston, 1991), however, knowledge of fish farming impacts in the Mediterranean Sea is scarce (Sarà et al., 2004, 2006; Vizzini \& Mazzola, 2004), which have different hydrographic characteristics, such as shallow waters and low current velocity areas, and are characterized by oligotrophic waters.

\subsection{Integrated multitrophic aquaculture}

The growing concern on aquaculture's environmental impact has led to an increasing research into feed formulations and digestibility, better conversion efficiency and improved management (Skalli et al., 2004; Troell et al., 2003). Since the last decade, the emphasis has been placed on the practice of integrated multi-trophic aquaculture (IMTA), with a potential to mitigate some of the environmental problems associated with mono-specific aquaculture (Soto et al., 2008). Originally used in freshwater practices, it involves the culture of two or more species from different trophic level; generally finfish being simultaneously cultured with both organic and inorganic extractive species, such as shellfish and seaweeds, respectively; in which by-products from one species are recycled to become inputs for another. Thus, the organic matter released in aquaculture systems might represent a source of available food for filter-feeding organisms, such as bivalves, reducing its impact on the environment (Shpigel et al., 1991) and can represent a potential economic income.

Filter feeders bivalves are essentially generalist consumers, and it has been demonstrated that they can exploit organic matter from several sources (autochthonous, allochthonous or anthropogenic), as a function of its availability (Stirling \& Okumus, 1995). In a conceptual open water integrated aquaculture, filter feeder bivalves are cultured adjacent to fish floating cages, reducing nutrient loadings by filtering and assimilating particulate wastes (uneaten food and faeces) as well as phytoplankton. In this way, bivalves would perform as biological filters. Previous studies have determined that bivalves can be successfully incorporated into integrated multitrophic aquaculture systems, based on the increased growth displayed and the feeding efficiency on pellet feed and fecal products (Mazzola \& Sarà, 2001; Reid et al., 2010).

\subsection{Stable isotopes as tracers of matter fluxes}

The use of stable isotopes in biogeochemistry and marine ecosystem analysis is increasing rapidly, especially in assessing trophic relationships and pathways of energy flow in food webs (Bergamino et al., 2011). Traditionally, the origin and fate of organic matter in the marine environment have been investigated through different approaches, such as lipid biomarkers or chlorophyll pigments. In filter feeder bivalves, it has been evaluated with gut content or fatty acid analyses, representing an instant snapshot of food ingested by bivalves. This limitation could be solved using stable isotope analyses, as the evaluation of food sources is based on assimilated instead of ingested food, which represents a time-integrated food utilization.

Stable isotope analysis is based on the assimilation of ${ }^{13} \mathrm{C}$ and $15 \mathrm{~N}$ from sources, with a slight enrichment of heavier isotopes $\left({ }^{13} \mathrm{C}\right.$ and $\left.{ }^{15} \mathrm{~N}\right)$ as lighter isotopes $\left({ }^{12} \mathrm{C}\right.$ and $\left.{ }^{14} \mathrm{~N}\right)$ are used in metabolism. The enrichment between prey and consumer tissues has been considered to be consistent across species, however, it has been demonstrated that it depends on the assimilation process and it has been set at $1 \%$ of ${ }^{13} \mathrm{C}$ and $3-4 \%$ of or ${ }^{15} \mathrm{~N}$ 
(De Niro \& Epstein, 1978; McCutchan et al., 2003). Since the ratio of ${ }^{12} \mathrm{C} /{ }^{13} \mathrm{C}$ isotopes changes little through the food web, this ratio is commonly used to distinguish between carbon sources, typically $\mathrm{C}_{3}$ or $\mathrm{C}_{4}$ and pelagic or benthic. In contrast, consumers showed a large amount of enrichment in nitrogen, thus, the ${ }^{14} \mathrm{~N} /{ }^{15} \mathrm{~N}$ ratio is commonly used to estimate trophic positions. Integrated multitrophic aquaculture involves species with different trophic strategies which can be positioned in the food web as a function of the ${ }^{13} \mathrm{C}$ and ${ }^{15} \mathrm{~N}$ stable isotope signatures.

\subsection{Objectives}

To decipher whether integrated multitrophic aquaculture is an effective method for minimizing and reducing waste inputs into the Mediterranean coastal ecosystem we have designed a multitrophic integrated system involving filter feeders bivalves (galloprovincialis (Lamarck, 1819) and Chlamys varia (Linnaeus, 1758)), and fin fish Argyrosomus regius (Asso, 1801). Through determination of carbon and nitrogen stable isotopes analyses to the several organisms and trophic strategies, the following aims will be accomplished:

i. Define the isotopic composition of the trophic food web of integrated multitrophic aquaculture in relation to two reference stations

ii. Study the temporal variability in waste matter fluxes at the different treatments, hence annual and seasonal variability

iii. Calculate the relative contributions of wastes (fresh food, pellets, plankton) to the fish farmed and to the filter feeders at the IMTA

\section{Methods}

\subsection{Experimental design for IMTA}

The study was conducted during years 2008, 2009 and 2010 at a research experimental station (LIMIA), on the SW coast of Mallorca, in Andratx Bay (39 32' 38.13" N, $2^{\circ} 22^{\prime} 51.08^{\prime \prime}$ E) (Figure 1). The installations included 6 floating cages for fish reproductive stages in the middle of the bay, with cultured Argyrosomus regius, with a total fish stock of 12-15 $\mathrm{t}$ year ${ }^{-1}$. Water depth ranged between 5 to 8 meters. Sediments surrounding fish cages were mostly unvegetated, except for disperse patches of Caulerpa prolifera (Forsskal) J.V.Lamouroux, 1809 within tens of meters distance. Current velocity below fish cages varied between 0 to 10 $\mathrm{cm} / \mathrm{s}$, with higher prevalence of very low current speeds (0 to $5 \mathrm{~cm} / \mathrm{s}$ ) (own data). Feed regime consisted in a combination of commercial dry pellets, CV4, Mar-9 vitalis repro and Gemma (Trouw S.A), hereafter called pellet 1, pellet 2 and pellet 3, respectively; and fresh food based on fishes Sardina pilchardus (Walbaum, 1792) (34.48 \%), Spicara smaris (Linnaeus, 1758) (24.14\%), Trachurus trachurus (Linnaeus, 1758) (31.03\%) and squid Loligo vulgaris Lamarck, 1798 (10.34 \%) on average ten times per month, with 10kg supplied each time.

Two reference sites were selected to evaluate the effects of aquaculture wastes in the adjacent

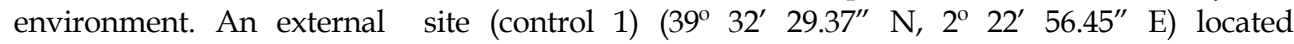
approximately $350 \mathrm{~m}$ away from the fish cages within the Andratx Bay, was selected to study the influence of the natural variability in the bay. The second site, (control 2) was located 21 nautical miles away from fish cages $\left(39^{\circ} 28^{\prime} 4^{\prime \prime} \mathrm{N}, 2^{\circ} 42^{\prime} 53^{\prime \prime} \mathrm{E}\right)$ in order to compare the isotopic values of the different components of the food web without the fish farm influence. 


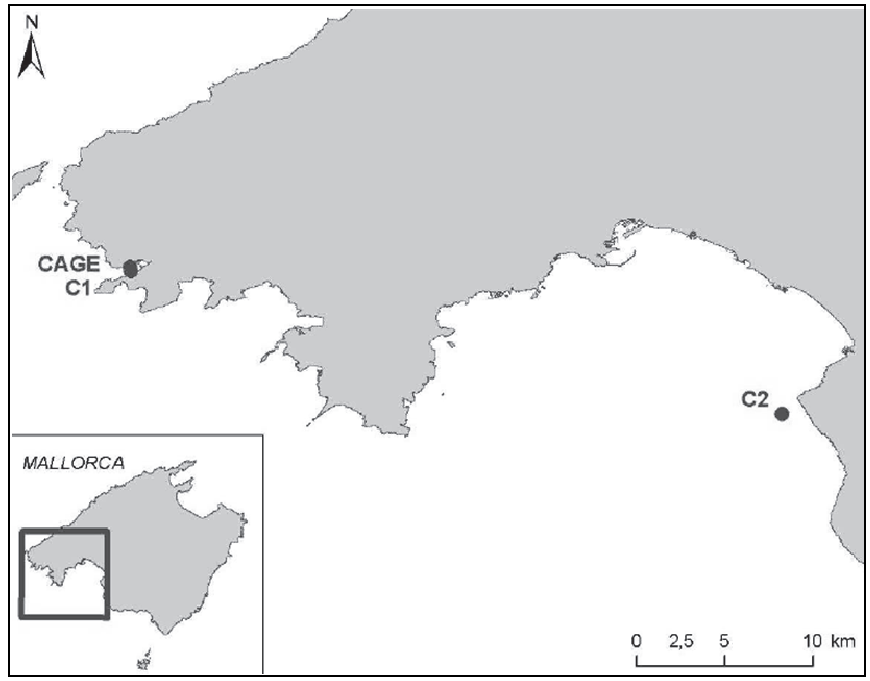

Fig. 1. Map of the SW coast of Mallorca. Solid circles indicate sampling sites (Cage: cage site, C1: control 1, C2: control 2).

Filter feeder bivalves Mytilus galloprovincialis and Chlamys varia were chosen for this study as they are native to the region, fast growing and commercially viable. They were collected from the harbor area in Andratx Bay between April and July 2007 and transferred to polyethylene plastic bags $(0.70 \times 0.40 \mathrm{~m}$ and $0.009 \mathrm{~m}$ mesh diameter) with a density of 250 Mytilus galloprovincialis/bag (size between 44 and $72 \mathrm{~mm}$ ) and 100 Chlamys varia/bag (size between 19 to $42 \mathrm{~mm}$ ). Forty plastic bags were placed hanging on fish cages, and the same amount was simultaneously attached to the rope buoys in control 1 and control 2 .

\subsection{Sampling and data collection}

\subsubsection{Cage site}

In the experimental site (hereafter called cage site), approximately 10 adult specimens of Argyrosomus regius, and 6 samples of Mytilus galloprovincialis and Chlamys varia (Linnaeus, 1758) were sampled seasonally. Additionally, potential food sources derived from aquaculture wastes as fish faeces and pellet and fresh food were sampled; as well as the other components of the marine food web, phytoplankton, zooplankton, particulate organic matter (POM) and sedimentary organic matter (SOM). Moreover, 5 sedimentivorous echinoderms Holothuria forskalii Delle Chiaje, 1823 were also collected.

Fish faeces were collected using pipettes after transferring adult Argyrosomus regius in a conical tank for an overnight evacuation. Individuals were then sacrificed in order to extract the muscle tissue from the left side of the posterior region to the dorsal fin using stainlesssteel tools, then, samples were cleaned thoroughly and rinsed with distilled water. Phytoplankton and zooplankton samples were collected using a plankton net $(100 \mu \mathrm{m}$ mesh size, $30 \mathrm{~cm}$ diameter) and a WP2 plankton net for zooplankton $(250 \mu \mathrm{m}$ mesh size, $45 \mathrm{~cm}$ diameter), respectively, which were towed through the water subsurface for 15 minutes at a velocity of 2 knots. 
Particulate organic matter, was sampled by vacuum filtering $10 \mathrm{~L}$ of seawater, collected using a $5 \mathrm{~L}$ Niskin bottle (General Oceanic, USA), through a pre-combusted $\left(450^{\circ} \mathrm{C}, 4\right.$ hours) Whatman GF/F glass microfiber filter, $1 \mathrm{~m}$ above the floating cages while in control sites, it was collected at the same depth as the filter feeders bivalves polyethylene bags. Sedimentary organic matter was collected by SCUBA divers from a quadrant surface (400 $\mathrm{cm}^{2}$ ) using hand cores.

\subsubsection{Control sites}

Similarly, in control sites, 6 specimens of filter feeder bivalves Mytilus galloprovincialis and Chlamys varia were sampled. In control 1 , Chlamys varia could not be sampled since the polyethylene bags were lost after severe storm periods. Moreover, phytoplankton, zooplankton, particulate organic matter (POM) and sedimentary organic matter (SOM) were sampled seasonally and 5 samples of sedimentivorous echinoderms Holothuria forskalii were sampled annually following the same procedure as in cage site (Table 1). All samples were frozen immediately after sampling and kept at $-20^{\circ} \mathrm{C}$ till further processing.

\subsection{Stable isotope analyses}

Samples were dried in an oven at $60^{\circ} \mathrm{C}$ for $24 \mathrm{~h}$ and subsequently grounded to a fine powder using a mortar and pestle. A minimum of two replicates for each sample was analyzed for $\delta^{13} \mathrm{C}$ and $\delta^{15} \mathrm{~N}$ isotopic signatures, except for commercial dry pellet feed which had a stable and controlled composition (Trouw S.A). SOM samples for $\delta^{13} \mathrm{C}$ isotopic analysis were acidified by adding $2 \mathrm{~N} \mathrm{HCl}$ (Carabel et al., 2006), while for $\delta^{15} \mathrm{~N}$ analysis, non- acidified replicates were used. From each sample $2 \pm 0.1 \mathrm{mg}$ of dry weight was placed in tin cups to determine the stable isotope ratios of carbon and nitrogen. The analyses were run at the SCTI (Scientific-Technical Services) from the Balearic Islands' University using a continuous flow mass spectrometer (Thermo Finnegan Delta x-plus). Reference standards were Vienne Pee Dee Belemnite (VPDB) for C and atmospheric nitrogen for N. One sample of an internal reference, Bovine Liver Standard (1577b) (U.S. Department of Commerce, National Institute of Standards and Technology, Gaithersburg, MD 20899), was analyzed every eight samples in order to calibrate the system and compensate the drift over time. The analytical precision of the stable isotope analyses was based on the standard deviation of the BSL samples; these deviations were $0.08 \%$ for $\delta^{13} \mathrm{C}$ and $0.09 \%$ for $\delta^{15} \mathrm{~N}$. Isotope ratios were expressed in $\delta^{13} \mathrm{C}$ and $\delta^{15} \mathrm{~N}$, with units of $\%$, according to the following equation:

$$
\delta^{13} \mathrm{C} \text { or } \delta^{15} \mathrm{~N}=\left[\left(\mathrm{R}_{\text {sample }} / \mathrm{R}_{\text {reference }}\right)-1\right] \times 1000
$$

Where $\mathrm{R}$ is the corresponding ${ }^{13} \mathrm{C} /{ }^{12} \mathrm{C}$ or ${ }^{15} \mathrm{~N} /{ }^{14} \mathrm{~N}$ ratio.

\subsubsection{Statistical analyses}

A distance-based permutational analysis of variance (PERMANOVA) on 999 permutations was employed to test the hypothesis that there were no differences in the isotopic signature $\left(\delta^{13} \mathrm{C}\right.$ and $\left.\delta^{15} \mathrm{~N}\right)$ of filter feeders bivalves between treatments and sampling periods. The factors Treatment (with three levels: cage, control 1 and control 2), Year (with three levels: 2008, 2009 and 2010) and Season nested in Year (with three factors: spring, summer and autumn) were treated as fixed. Additionally, a distance-based test for homogeneity of 


\begin{tabular}{|c|c|c|c|c|c|}
\hline Sample & Treatment & 2008 & 2009 & 2010 & Perodicity \\
\hline \multicolumn{6}{|l|}{ Fin Fish } \\
\hline Argyrosomus regius & cage & $x$ & $x$ & $x$ & Seasonal \\
\hline \multicolumn{6}{|l|}{ Filter feeders } \\
\hline Mytilus galloprovincialis & cage & $x$ & $x$ & $x$ & Seasonal \\
\hline Mytilus galloprovincialis & control 1 & $x$ & $x$ & $x$ & Seasonal \\
\hline Mytilus galloprovincialis & control 2 & $x$ & $x$ & $x$ & Seasonal \\
\hline Chlamys varia & cage & $x$ & $x$ & $x$ & Seasonal \\
\hline Chlamys varia & control 1 & - & - & - & Seasonal \\
\hline Chlamys varia & control 2 & - & $x$ & $x$ & Seasonal \\
\hline \multicolumn{6}{|l|}{ Sedimentivorous } \\
\hline Holothuria forskalii & cage & - & $x$ & $x$ & Anual \\
\hline Holothuria forskalii & control 1 & - & $x$ & $x$ & Anual \\
\hline Holothuria forskalii & control 2 & - & $x$ & $x$ & Anual \\
\hline \multicolumn{6}{|l|}{ Food sources } \\
\hline \multicolumn{6}{|l|}{ Pellet food } \\
\hline Pellet 1 (CV4) & cage & $x$ & - & - & Anual \\
\hline Pellet 2 (Mar-9 vitalis repro) & cage & $x$ & - & - & Anual \\
\hline Pellet 3 (Gemma) & cage & $x$ & - & - & Anual \\
\hline \multicolumn{6}{|l|}{ Fresh food } \\
\hline Loligo vulgaris & cage & $x$ & $x$ & - & Seasonal \\
\hline Sardina pilchardus & cage & $x$ & $x$ & - & Seasonal \\
\hline Spicara smaris & cage & $x$ & $x$ & - & Seasonal \\
\hline Trachurus trachurus & cage & $x$ & $x$ & - & Seasonal \\
\hline \multicolumn{6}{|l|}{ Organic matter sources } \\
\hline Phytoplankton & cage & - & $x$ & $x$ & Seasonal \\
\hline Phytoplankton & control 1 & - & $x$ & $x$ & Seasonal \\
\hline Phytoplankton & control 2 & - & $x$ & $x$ & Seasonal \\
\hline Zooplankton & cage & $x$ & $x$ & $x$ & Seasonal \\
\hline Zooplankton & control 1 & $x$ & $x$ & $x$ & Seasonal \\
\hline Zooplankton & control 2 & $x$ & $x$ & $x$ & Seasonal \\
\hline POM & cage & $x$ & $x$ & $x$ & Seasonal \\
\hline POM & control 1 & $x$ & $x$ & $x$ & Seasonal \\
\hline POM & control 2 & $x$ & $x$ & $x$ & Seasonal \\
\hline SOM & cage & $x$ & $x$ & $x$ & Seasonal \\
\hline SOM & control 1 & $x$ & $x$ & $x$ & Seasonal \\
\hline SOM & control 2 & $x$ & $x$ & $x$ & Seasonal \\
\hline
\end{tabular}

Table 1. List of samples collected during the three years of the study in each location with its periodicity. (X: sample collected and -: sample not collected). 
dispersions (PERMDISP) was used to analyze the multivariate dispersion for each treatment at all sampling sites. All statistical computations were performed using the statistical package PRIMER® 6.0 software. The permutational analysis (PERMANOVA) was not performed on $\delta^{13} \mathrm{C}$ and $\delta^{15} \mathrm{~N}$ sediment data in years 2009 and 2010 because, as a consequence of the low carbon and nitrogen content in the samples, some replicates did not reach the mass requirements and could not be analyzed in the mass spectrometer.

\subsubsection{Partial contributions of aquaculture wastes at the studied food webs}

Stable isotope mixing models are an increasingly common approach in environmental sciences. They are used to determine the proportional contribution of sources to a mixture based on their respective isotope signatures (Phillips \& Gregg, 2001). Amongst its application we can find the estimation of the relative importance of food sources to animal diets, pollution sources to air or water bodies and carbon sources to soil organic matter (Michener \& Lajtha, 2007).

In this study, we applied the SISUS Bayesian Mixing model (Stable Isotope Sourcing using Sampling) to quantify the feasible contributions of the potential organic matter sources (phytoplankton, zooplankton, POM, faecal material, pellet and fresh food) to the filter feeders bivalves' diet, based on the analyzed stable isotope ratios. Considering the specific isotope enrichment between prey and consumer tissues, a discrimination of $0.3 \%$ for carbon was assumed for POM and filter feeders bivalves; while for muscle tissue samples of Argyrosomus regius a $1.3 \%$ was applied. Previous studies have shown that trophic fractionation is much larger for $\delta^{15} \mathrm{~N}$ than for $\delta^{13} \mathrm{C}$, so a correction of $2.3 \%$ o per trophic level was applied (McCutchan et al., 2003).

The model is based on a modification of the Isosource programme (Phillips \& Gregg, 2001), which creates every possible combination of source proportions and compares these predicted mixtures signatures with the observed mixtures signatures. If they are equal or within some small tolerance range, this combination represents a feasible solution. The SISUS software is available for public use at http://statacumen.com/sisus/.

\section{Results}

\subsection{Isotopic composition of the marine food web components at IMTA}

The carbon and nitrogen isotopic composition of the marine food components analyzed in the three years of study in cage and control sites are summarized in Figures 2, 3 and 4.

\subsubsection{Potential organic matter sources and environmental elements}

Commercial pellet food supplied in the fish farm had similar isotopic values of $\delta^{13} \mathrm{C}$ (between $-20.78 \%$ o to $-21.87 \%$ ), with an average value of $-21.17 \pm 0.09 \%$; however, they differed greatly in $\delta^{15} \mathrm{~N}$ values (between $14.93 \%$ and $6.20 \%$ ), with pellet 2 being the most enriched source in ${ }^{15} \mathrm{~N}$, in contrast to pellet 1 which was the most depleted nitrogen source. Fresh food were ${ }^{13} \mathrm{C}$ - enriched compared to pellet food, on average $2 \%$ o ( mean $-19.1 \pm 0.19$ $\%$ ), in contrast, $\delta^{15} \mathrm{~N}$ values were relatively similar. Considering all individual sources, fresh food sources had similar values of $\delta^{13} \mathrm{C}$ (between $-18.82 \%$ to $-19.19 \%$ ), but they showed differences in $\delta^{15} \mathrm{~N}$ values, ranging between $7.92 \%$ to $12.46 \%$, with Loligo vulgaris as the most enriched source in ${ }^{15} \mathrm{~N}$ and Spicara smaris the most depleted. 


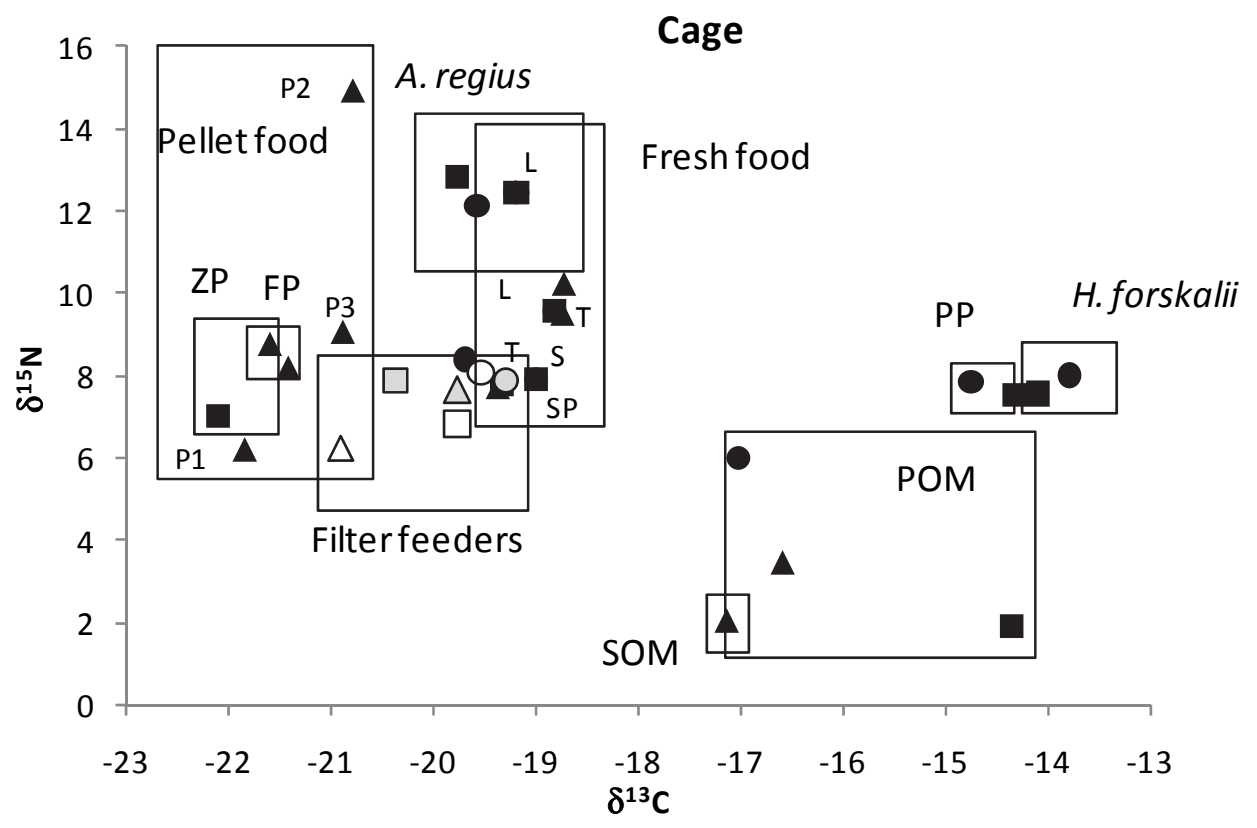

Fig. 2. Mean $\delta^{13} \mathrm{C}$ and $\delta^{15} \mathrm{~N}$ values of samples in the cage site in years $2008(\boldsymbol{\Delta}), 2009(\boldsymbol{\bullet})$ and 2010 (•). ZP: zooplankton; PP: phytoplankton; FP: Argyrosomus regius fish faeces; S: Sardina pilchardus; SP: Spicara smaris, T: Trachurus trachurus; L: Loligo vulgaris; P1: pellet 1; P2: pellet 2; P3: pellet 3; POM: particulate organic matter and SOM: sedimentary organic matter. Filter feeders include Chlamys varia (grey symbol) and Mytilus galloprovincialis (white symbol).

Sardina pilchardus, Spicara smaris, Trachurus trachurus and Loligo vulgaris are classified as fresh food.

Throughout the sampling period, Argyrosomus regius' carbon isotopic signature was, on average, $-19.06 \pm 0.64 \%$, (ranging between $-18.72 \%$ o to $-19.77 \%$ o), while for nitrogen it was, on average, $11.45 \pm 1.12 \%$, (ranging between $10.24 \%$ o to $12.83 \%$ ). Concerning the isotopicstep enrichment, the value of fish faeces was ${ }^{13} \mathrm{C}$ - depleted compared to the muscle isotopic signature, with a mean decrease of $1.61 \pm 0.55 \%$. For ${ }^{15} \mathrm{~N}$, the depletion was more pronounced, with a mean decrease of $3.34 \pm 1.34 \%$.

Regarding the phytoplankton fraction, in the three years of study, phytoplankton from cage site exhibited similar values of $\delta^{13} \mathrm{C}$ and $\delta^{15} \mathrm{~N}$, with mean values of $-14.54 \pm 0.29 \%$ and 7.70 $\pm 0.22 \%$, respectively. Values in control sites showed little variability, with mean values of $15.04 \pm 0.41 \%$ and $7.10 \pm 1.06 \%$ for $\delta^{13} \mathrm{C}$ and $\delta^{15} \mathrm{~N}$ in control 1 ; and $-19.44 \pm 0.44 \%$ and 5.25 $\pm 1.25 \%$ or for $\delta^{13} \mathrm{C}$ and $\delta^{15} \mathrm{~N}$ in control 2, respectively. For zooplankton, mean values in cage site were $-21.13 \pm 1.27 \%$ for $\delta^{13} \mathrm{C}$ and $8.06 \pm 0.91 \%$ or $\delta^{15} \mathrm{~N}$. Values from control 1 showed more variability; with mean values of $-18.49 \pm 3.56 \%$ for $\delta 13 \mathrm{C}$ and $7.97 \pm 0.91 \%$ o for $\delta 15 \mathrm{~N}$, while in control 2 values were of $-17.39 \pm 0.37 \%$ and $5.91 \pm 1.30 \%$ o for $\delta^{13} \mathrm{C}$ and $\delta^{15} \mathrm{~N}$, respectively. Comparing $\delta^{13} \mathrm{C}$ and $\delta^{15} \mathrm{~N}$ values from cage site relative to control sites, phytoplankton from cage site showed a slightly enrichment in ${ }^{13} \mathrm{C}$ relative to control 1 , on average $0.59 \%$; differences were more pronounced relative to control 2 , with an average 


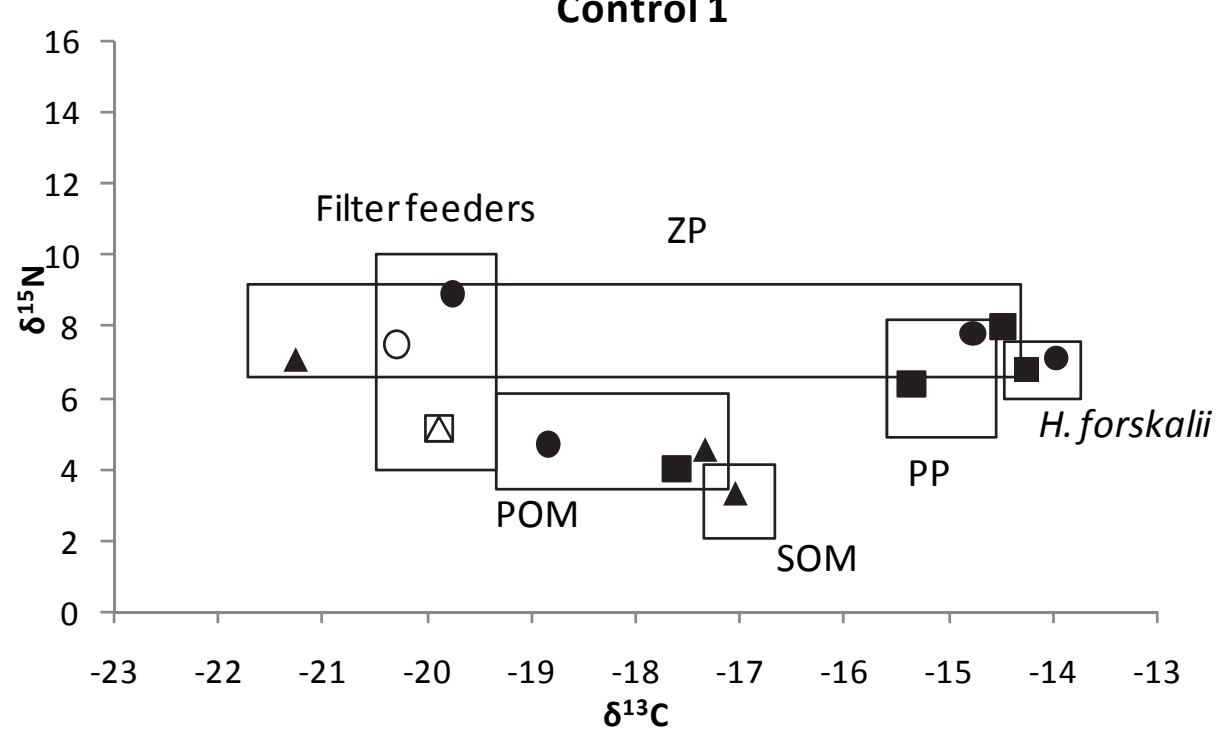

Fig. 3. Mean $\delta^{13} \mathrm{C}$ and $\delta^{15} \mathrm{~N}$ values of the different samples in control 1 in years $2008(\mathbf{\Delta})$, 2009 (๘) and $2010(\bullet)$. ZP: zooplankton; PP: phytoplankton; POM: particulate organic matter and SOM: sedimentary organic matter. Filter feeders include Mytilus galloprovincialis (white symbol).

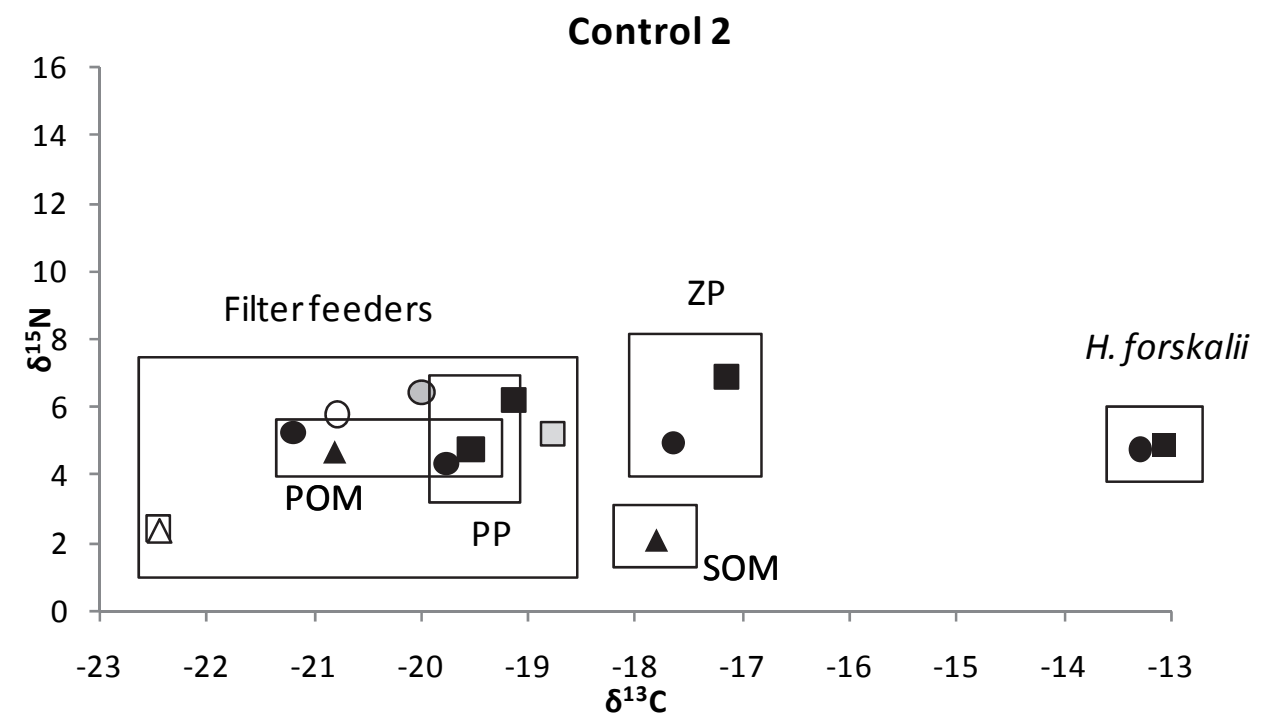

Fig. 4. Mean $\delta^{13} \mathrm{C}$ and $\delta^{15} \mathrm{~N}$ values of the different samples in the control 2 in years $2008(\boldsymbol{\Delta})$, 2009 (घ) and 2010 (•). ZP: zooplankton; PP: phytoplankton; POM: particulate organic matter and SOM: sedimentary organic matter. Filter feeders include Mytilus galloprovincialis (white symbol) and Chlamys varia (grey symbol). 
enrichment of $4.38 \%$. For $\delta^{15} \mathrm{~N}$ values, phytoplankton from cage site, was enriched on average a $1.35 \%$ relative to control 1 and $1.56 \%$ relative to control 2 . The same pattern existed for zooplankton, with an average enrichment of $2.63 \%$ and $3.73 \%$ in ${ }^{13} \mathrm{C}$ relative to control 1 and control 2, respectively; while for nitrogen, the enrichment relative to control 1 and control 2 was on average, $0.09 \%$ and $2.15 \%$, respectively.

Particulate organic matter (POM) from cage site showed mean values of $-15.98 \pm 1.43 \%$ and $3.78 \pm 2.06 \%$ for $\delta^{13} \mathrm{C}$ and $\delta^{15} \mathrm{~N}$, showing an enrichment in ${ }^{13} \mathrm{C}$ and ${ }^{15} \mathrm{~N}$ relative to control 1 and control 2, with average values of $1.93 \%$ and $0.62 \%$ in ${ }^{13} \mathrm{C}$ and $0.62 \%$ and $1.10 \%$ in ${ }_{15} \mathrm{~N}$, respectively. As in phytoplankton and zooplankton, differences were more pronounced when comparing cage site with the distant control site, control 2. On the contrary, $\delta^{13} \mathrm{C}$ and $\delta{ }^{15} \mathrm{~N}$ sedimentary organic matter $(\mathrm{SOM})$ values from cage site and control 1 were relatively similar, with mean values of $-17.13 \%$ and $2.04 \%$ or for $\delta^{13} \mathrm{C}$ and $\delta^{15} \mathrm{~N}$ in cage site and -17.04 $\%$ and $3.34 \%$ for $\delta^{13} \mathrm{C}$ and $\delta^{15} \mathrm{~N}$ in control 1. Relative to control 2, cage site was enriched in ${ }^{13} \mathrm{C}$ a $0.67 \%$ while for ${ }^{15} \mathrm{~N}$ the enrichment was only $0.06 \%$

Sedimentivorous echinoderm Holothuria forskkalii showed mean values of $-13.95 \pm 0.28 \%$ and $7.77 \pm 0.56 \%$ or for $\delta^{13} \mathrm{C}$ and $\delta^{15} \mathrm{~N}$, respectively in cage site. Average values in control 1 were $-14.10 \pm 0.64 \%$ and $7.04 \pm 0.27 \%$ for $\delta^{13} \mathrm{C}$ and $\delta^{15} \mathrm{~N}$, respectively and in control 2 of $13.19 \pm 0.62 \%$ and of $4.82 \pm 0.65 \%$ for $\delta^{13} \mathrm{C}$ and $\delta^{15} \mathrm{~N}$, respectively. Comparing cage site with control sites, an enrichment of $0.79 \%$ in ${ }^{13} \mathrm{C}$ relative to control 2 was observed, while control 1 values were depleted in a $0.15 \%$ o for ${ }^{13} \mathrm{C}$. For ${ }^{15} \mathrm{~N}$, it was observed an enrichment of $0.73 \%$ and $2.93 \%$ relative to control 1 and 2 , respectively.

\subsubsection{Filter feeder bivalves and temporal variability in isotopic signals among treatments}

Filter feeders bivalves collected in the cage site exhibited similar isotopic values, ranging from $-20.73 \%$ o to $-20.90 \%$ or for ${ }^{13} \mathrm{C}$ and $6.26 \%$ to $6.36 \%$ for ${ }^{15} \mathrm{~N}$ in Mytilus galloprovincialis, and between $-19.41 \%$ o to $-19.76 \%$ or for ${ }^{13} \mathrm{C}$ and $7.33 \%$ o to $7.64 \%$ or for ${ }^{15} \mathrm{~N}$ in Chlamys varia. Statistical analyses showed significant differences between cage and control treatments in the three years of study with filter feeder bivalves from fish cages enriched in both ${ }^{13} \mathrm{C}$ and ${ }^{15 N}$ (PERMANOVA, $\mathrm{p}<0.05$ ) (Table 2 and 3). Mytilus galloprovincialis of cage site showed an

\begin{tabular}{|c|c|c|c|c|c|c|c|c|}
\hline & $\delta^{13} \mathrm{C}$ & & & & $\delta^{15} \mathrm{~N}$ & & & \\
\hline Source of variation & $\mathrm{df}$ & SS & MS & Pseudo-F & $\mathrm{df}$ & SS & MS & Pseudo-F \\
\hline $\operatorname{Tr}$ & 2 & 18.07 & 9.0352 & $20.743^{*}$ & 2 & 17.327 & 8.6634 & $19.53^{*}$ \\
\hline Ye & 2 & 10.524 & 5.2618 & $12.08^{*}$ & 2 & 2.1712 & 1.0856 & 2.44 \\
\hline $\mathrm{Se}(\mathrm{Ye})$ & 4 & 17.003 & 4.2509 & $9.75^{*}$ & 4 & 31.434 & 7.8584 & $17.72^{*}$ \\
\hline TrxYe & 1 & 1.6363 & 1.6363 & 3.75 & 1 & 8.6544 & 8.6544 & $19.51^{*}$ \\
\hline TrxSe(Ye) & 1 & 3.9901 & 3.9901 & $9.16^{*}$ & 1 & 0.47796 & 0.47796 & 1.078 \\
\hline Res & 107 & 46.607 & 0.43558 & & 107 & 47.442 & 0.44338 & \\
\hline Total & 117 & 93.894 & & & 117 & 135.58 & & \\
\hline
\end{tabular}

Table 2. Results of the 3-way PERMANOVA, mixed design, with "Treatment" (Tr), "Year" (Ye) and "Season"(Se) as fixed factors. The analysis is based on the modified Euclidean distance dissimilarity of the Mytilus galloprovincialis isotopic signatures of $\delta^{13} \mathrm{C}$ and $\delta^{15} \mathrm{~N}(999$ permutations). The studied factors were 3 treatments (cage, control 1 and control 2), three years $\left(2008,2009\right.$ and 2010) and three seasons (spring, summer and autumn). ${ }^{*} \mathrm{p}<0.05$ 


\begin{tabular}{|c|c|c|c|c|c|c|c|c|}
\hline \multirow[b]{2}{*}{ Sources of variation } & \multicolumn{2}{|c|}{$\delta^{13} \mathrm{C}$} & \multirow[b]{2}{*}{ MS } & \multirow[b]{2}{*}{ Pseudo-F } & \multicolumn{2}{|c|}{$\delta^{15} \mathrm{~N}$} & \multirow[b]{2}{*}{ MS } & \multirow[b]{2}{*}{ Pseudo-F } \\
\hline & $\mathrm{df}$ & SS & & & $\mathrm{df}$ & SS & & \\
\hline $\operatorname{Tr}$ & 2 & 17.403 & 8.7017 & $16.71^{*}$ & 2 & 22.21 & 11.105 & $37.24^{*}$ \\
\hline Ye & 2 & 29.116 & 14.558 & $27.97^{*}$ & 2 & 2.8058 & 1.4029 & $4.70^{*}$ \\
\hline $\mathrm{Se}(\mathrm{Ye})$ & 4 & 24.883 & 6.2208 & $11.95^{*}$ & 4 & 40.425 & 10.106 & $33.89^{*}$ \\
\hline TrxYe & 0 & 0 & & No test & 0 & 0 & & No test \\
\hline TrxSe(Ye) & 1 & 0.099525 & 0.099525 & 0.19 & 1 & 1.0493 & 1.0493 & 3.51 \\
\hline Res & 83 & 43.2 & 0.52048 & & 83 & 24.745 & 0.29814 & \\
\hline Total & 92 & 88.919 & & & 92 & 92.935 & & \\
\hline
\end{tabular}

Table 3. Results of the 3-way PERMANOVA, mixed design, with "Treatment" (Tr), "Year" (Ye) and "Season"(Se) "as fixed factors. The analysis is based on the modified Euclidean distance dissimilarity of the Chlamys varia isotopic signatures of $\delta^{13} \mathrm{C}$ and $\delta^{15} \mathrm{~N}(999$ permutations). The studied factors were 3 treatments (cage, control 1 and control 2), three years $\left(2008,2009\right.$ and 2010) and three seasons (spring, summer and autumn). ${ }^{*} \mathrm{p}<0.05$

enrichment of $0.52 \%$ in ${ }^{13} \mathrm{C}$ and $0.75 \%$ in ${ }^{15} \mathrm{~N}$ compared to bivalves from control 1; greatest differences were found when comparing cage site with control 2, with an enrichment of 0.75 $\%$ in ${ }^{13} \mathrm{C}$ and $1.69 \%$ in ${ }^{15} \mathrm{~N}(\mathrm{p}<0.05)$ (Figure 5 and 6$)$. Chlamys varia from cage site showed a large amount of enrichment compared to control 2, $1.11 \%$ and $1.71 \%$ in ${ }^{13} \mathrm{C}$ and ${ }^{15} \mathrm{~N}$, respectively (Figure 7 and 8 ).

\subsection{Contribution of organic and inorganic matter sources to different consumers of the multitrophic system}

According to the bayesian mixing model, the main food source for the fish Argyrosomus regius was pellet food, with a mean global contribution of $80.43 \%$ (from pellet 1, 2 and 3), while the remaining $19.57 \%$ corresponded to fresh food. Contributions varied annually, 67.7 $\%, 91.53 \%$ and $82 \%$ for pellet food and $32.3 \%, 8.5 \%$ and $18 \%$ for fresh food in years 2008 , 2009 and 2010, respectively (Figure 9). In the first year of study, pellet 1 was the main pellet food source, while Sardina pilchardus and Spicara smaris were the main fresh food sources; the main pellet food source changed to be pellet 2 the following year, while in 2010 the main source was again pellet 1; Sardina pilchardus and Spicara smaris remained the main fresh food sources along the remaining years of study.

In filter feeder bivalve Chlamys varia, pellet food was the main food source, with a mean contribution of up to $62.68 \%$ of their isotopic composition in the three years of study, followed by fresh food, POM, fish faeces and phytoplankton, with a mean contribution of $18.28 \%, 11.26$ $\%, 5.18 \%$ and $2.58 \%$, respectively. Contributions of the five organic matter sources varied both seasonally and annually (Figure 10), however, aquaculture derived products, as pellet and fresh food and fish faeces remained the main food sources along the three years of study varying from $70.03 \%$ in spring 2009 to the maximum of $93.81 \%$ in autumn 2010. Regarding the seasonal variation, there was a fluctuation in the contribution of pellet food, with a medium contribution in spring, fewer in summer and a higher contribution in autumn. Summer 2009 showed a different pattern with a contribution of $81.74 \%$ of pellet food. Regarding pellet food sources, pellet 1 was the main source in the three years of study, with a contribution fluctuating between $18.72 \%$ and $81.74 \%$, while for fresh food the main contribution was from Sardina pilchardus and Spicara smaris. Particulate organic matter (POM) also showed variation, with the lowest contribution in autumn 2009 (4.24\%) and the 


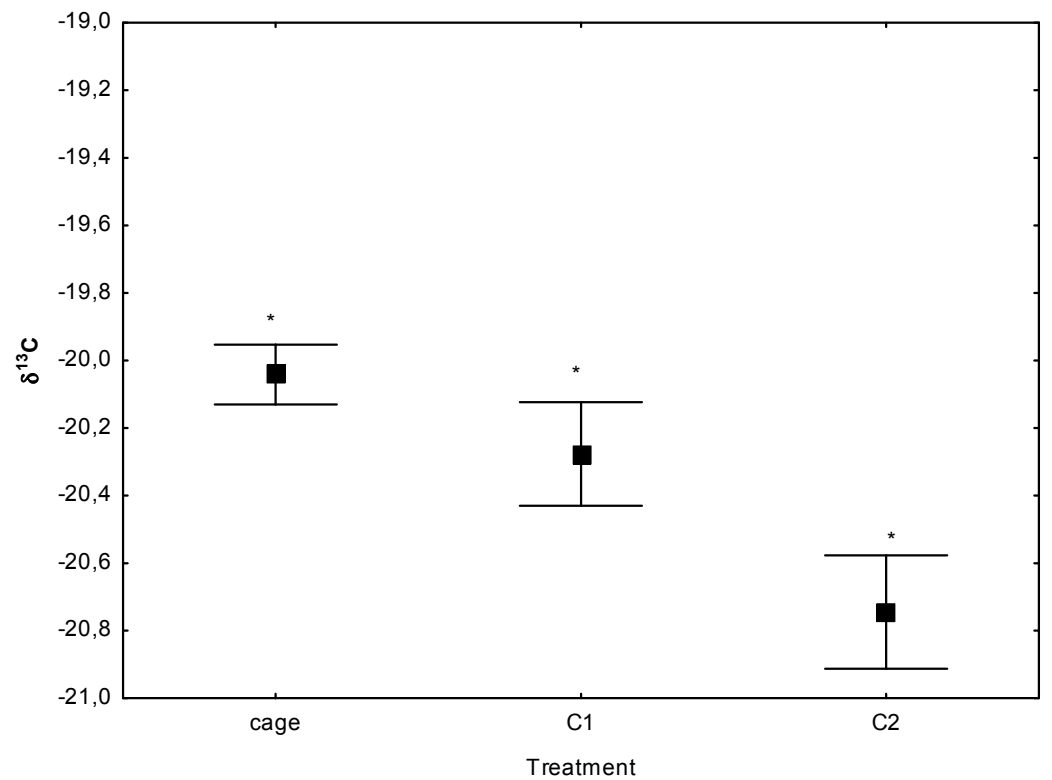

Fig. 5. Mean $\delta^{13} \mathrm{C}$ (mean $\pm \mathrm{SE}$ ) values for the three studied years of bivalve Mytilus galloprovincialis in the study sites: cage, control 1 (C1) and control 2 (C2). (PERMANOVA test, $\left.{ }^{*} \mathrm{p}<0.05\right)$.

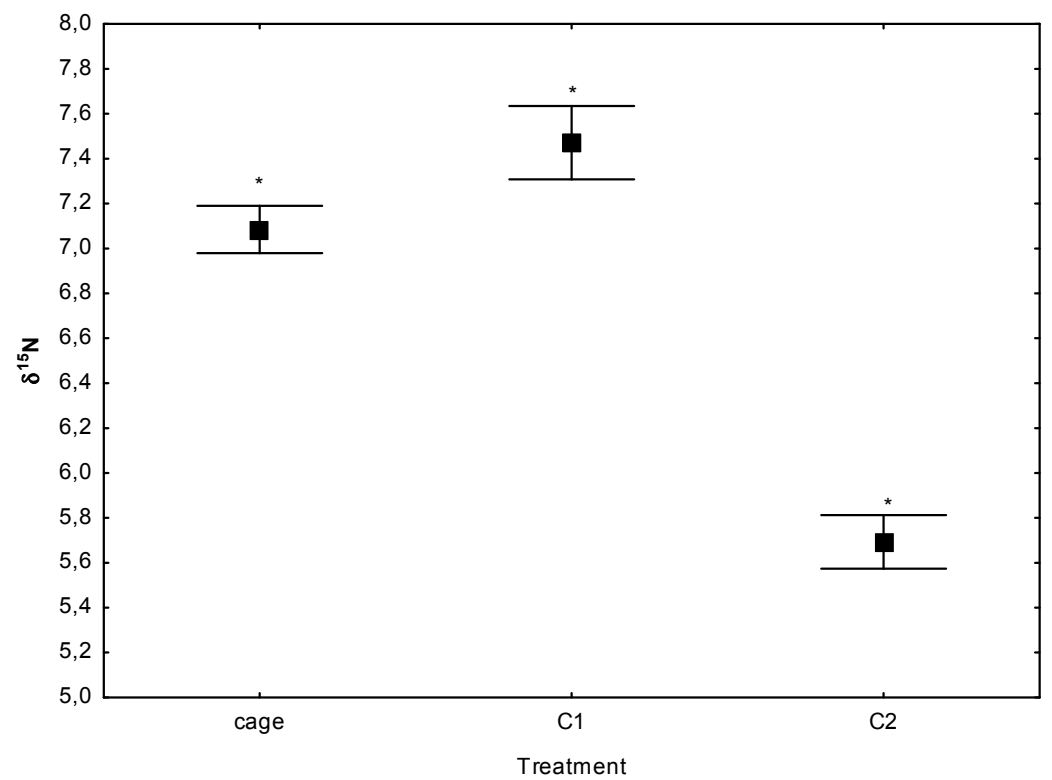

Fig. 6. Mean $\delta^{15} \mathrm{~N}$ value for the three studied years (mean $\pm \mathrm{SE}$ ) of bivalve Mytilus galloprovincialis in the study sites: cage, control 1 (C1) and control 2 (C2) . (PERMANOVA test, $\left.{ }^{*} \mathrm{p}<0.05\right)$. 


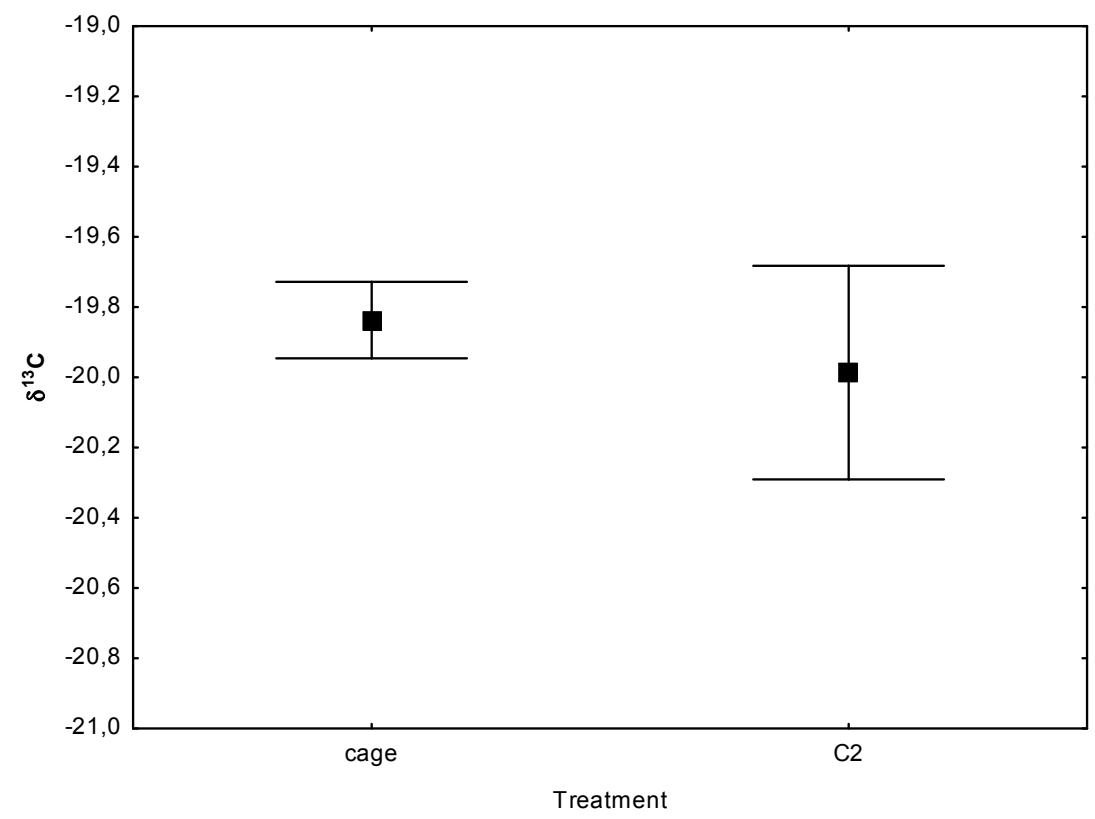

Fig. 7. Mean $\delta^{13} \mathrm{C}$ (mean $\pm \mathrm{SE}$ ) values for the three studied years of bivalve Chlamys varia in the study sites: cage and control $2(\mathrm{C} 2)$.

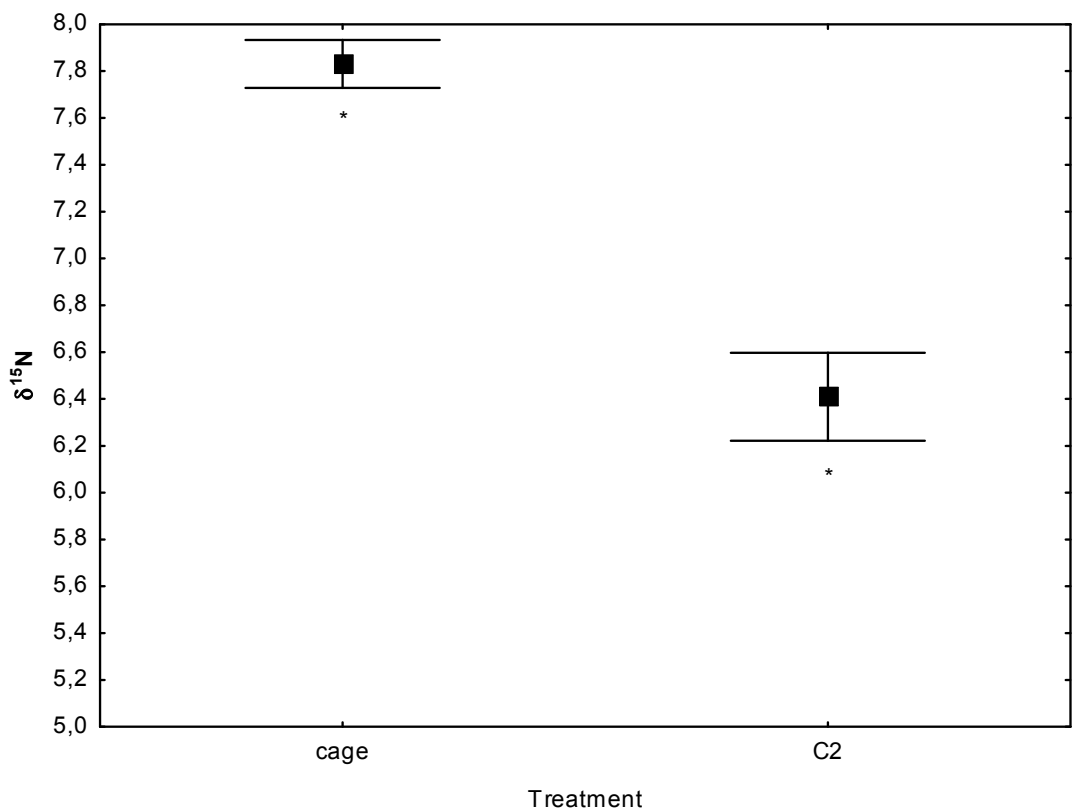

Fig. 8. Mean $\delta^{15} \mathrm{~N}$ value for the three studied years (mean $\pm \mathrm{SE}$ ) of bivalve Chlamys varia in the study sites: cage, and control 2 (C2). (PERMANOVA test, $\left.{ }^{*} \mathrm{p}<0.05\right)$. 


\section{Argyrosomus regius}

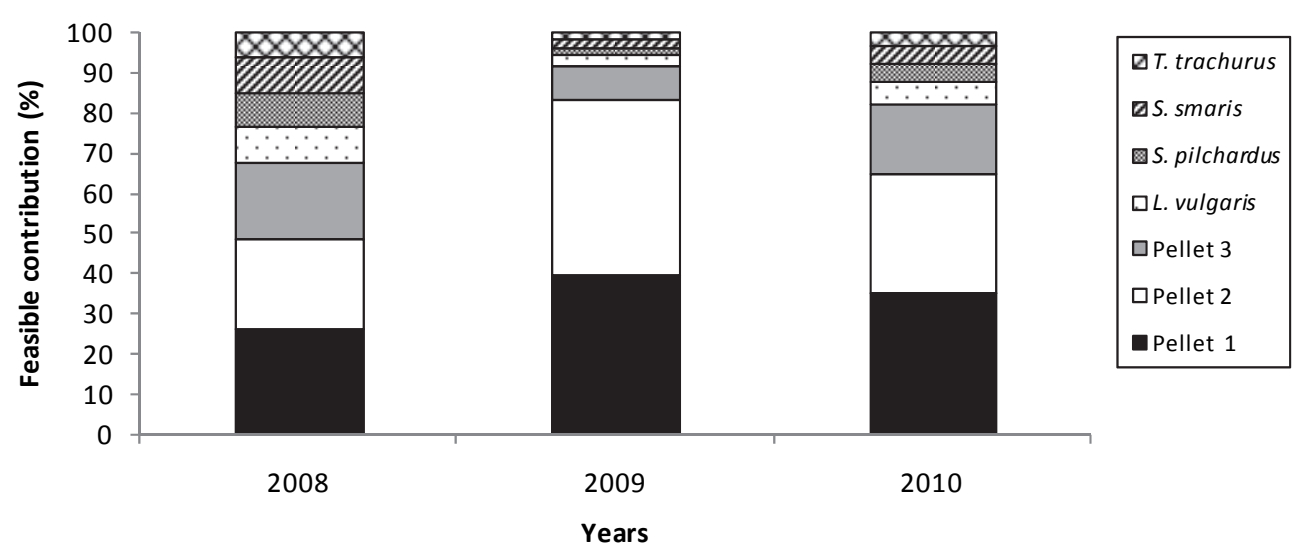

Fig. 9. Annual variation of the feasible contribution (\%) of pellet and fresh food to the diet of cultured Argyrosomus regius based on Bayesian mixing models.

\section{Chlamys varia}

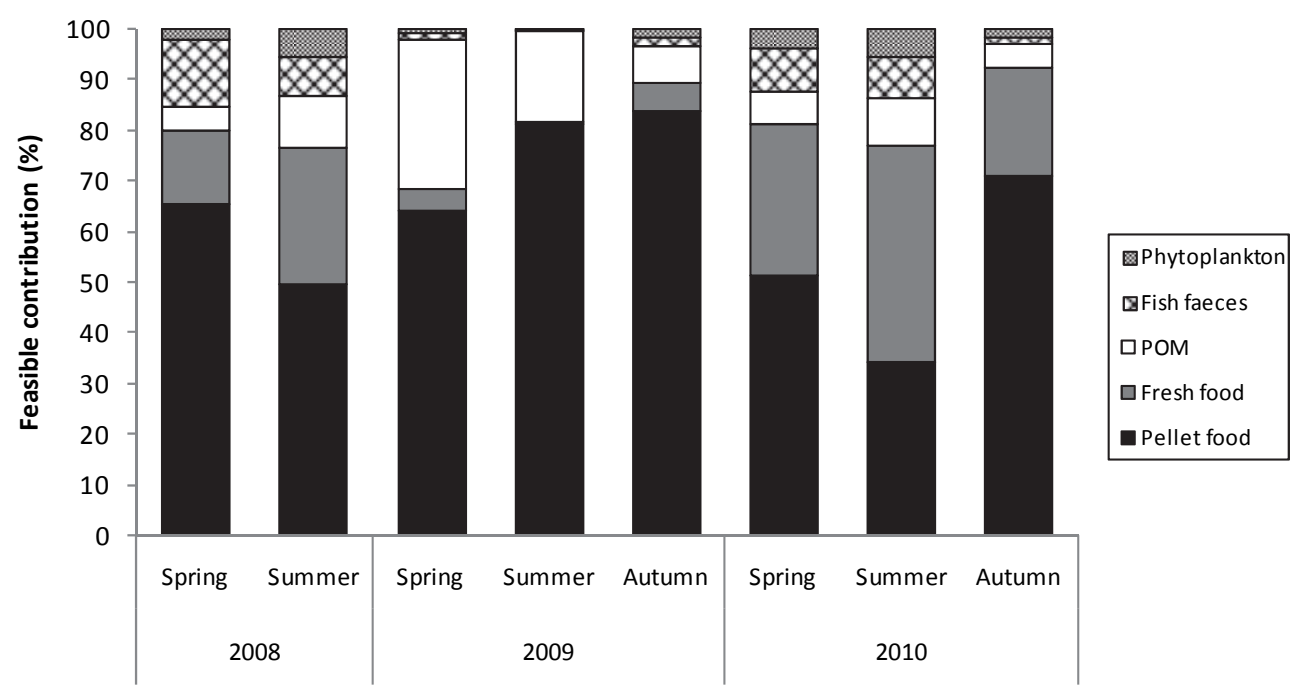

Fig. 10. Seasonal and annual variability of the feasible contribution of the main organic matter sources to the diet of Chlamys varia cultured in fish cages based on Bayesian mixing models. 
highest in spring 2009 (29.39\%). Especially remarkable is the low contribution of phytoplankton, with values from $0.06 \%$ in summer 2009 to $5.27 \%$ in summer 2008 .

Similarly, pellet food was the main food source for Mytilus galloprovincialis, with a mean contribution of $57.95 \%$, followed by fresh food (21.46\%), fish faeces $(8.90 \%)$, POM $(7.84 \%)$ and phytoplankton (3.83 \%). Contributions also varied seasonally and annually, but again aquaculture derived products remained the main food sources in the three years of study, with mean values varying from $82.79 \%$ in spring 2009 to $97.7 \%$ in spring 2008 . Contrary to Chlamys varia, pellet food contribution was higher in spring and decreased in summer and autumn (Figure 11). Regarding the different commercial pellet food, similar to Chlamys varia pellet 1 was the main contributor, especially in spring 2008 were it represented up to $82 \%$ of the total isotopic composition. Sardina pilchardus and Spicara smaris were the main sources among the fresh food supplied in fish cages. POM showed a lower contribution in the isotopic composition of Mytilus galloprovincialis than in Chlamys varia, with values ranging between $1.85 \%$ in spring 2008 to $14.79 \%$ in spring 2009. Contribution of phytoplankton was slightly higher than in Chlamys varia, with values between $0.87 \%$ in spring 2008 to nearly $17.50 \%$ in autumn 2009.

Mytilus galloprovincialis

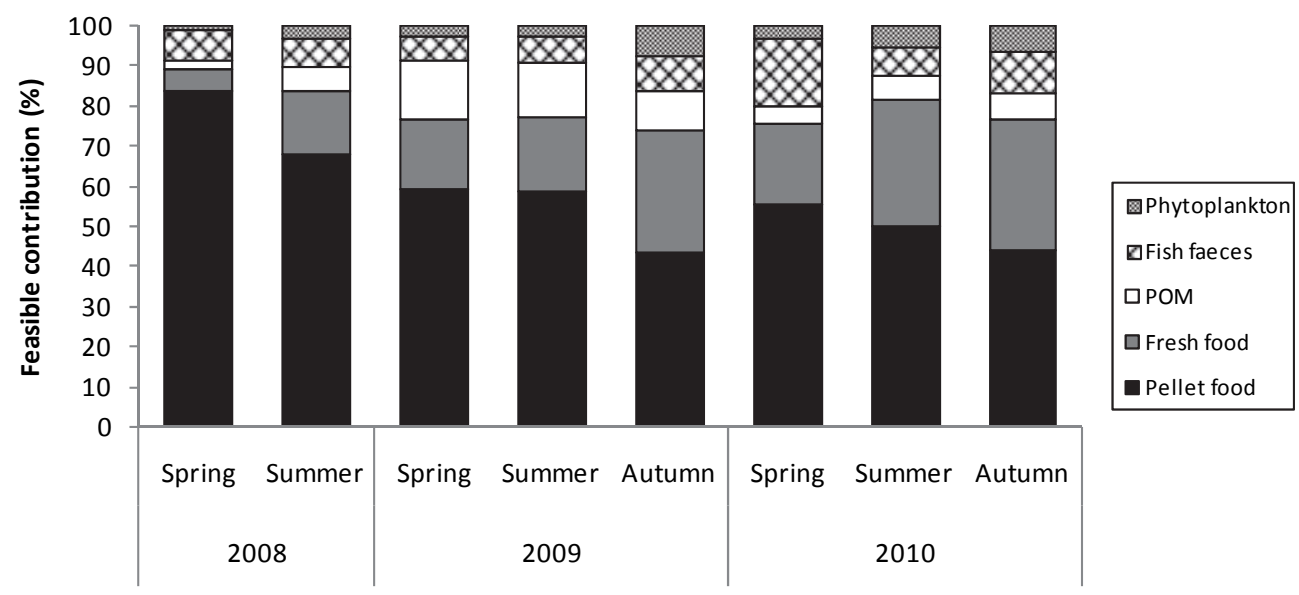

Fig. 11. Seasonal and annual variability of the feasible contribution of the main organic matter sources to the diet of Mytilus galloprovincialis cultured in fish cages calculated by Bayesian mixing models.

The mean feasible contribution of organic matter sources in sedimentivorous Holothuria forskalii was also analysed to study whereas there was an influence of organic enrichment in the benthic population (Figure 12). According to Bayesian mixing model, POM was the main food source, with a mean contribution of $48.56 \%$ in the years of study. Contribution of aquaculture derived products as pellet and fresh food, and fish faeces was remarkable, with a $28.11 \%$. Bayesian mixing model was also applied to POM to elucidate its composition, with nearly the $50 \%$ of its isotopic signature coming from phytoplankton (Figure 13). The contribution of aquaculture derived products was also remarkable, with nearly $30 \%$. 


\section{H. forskalii}

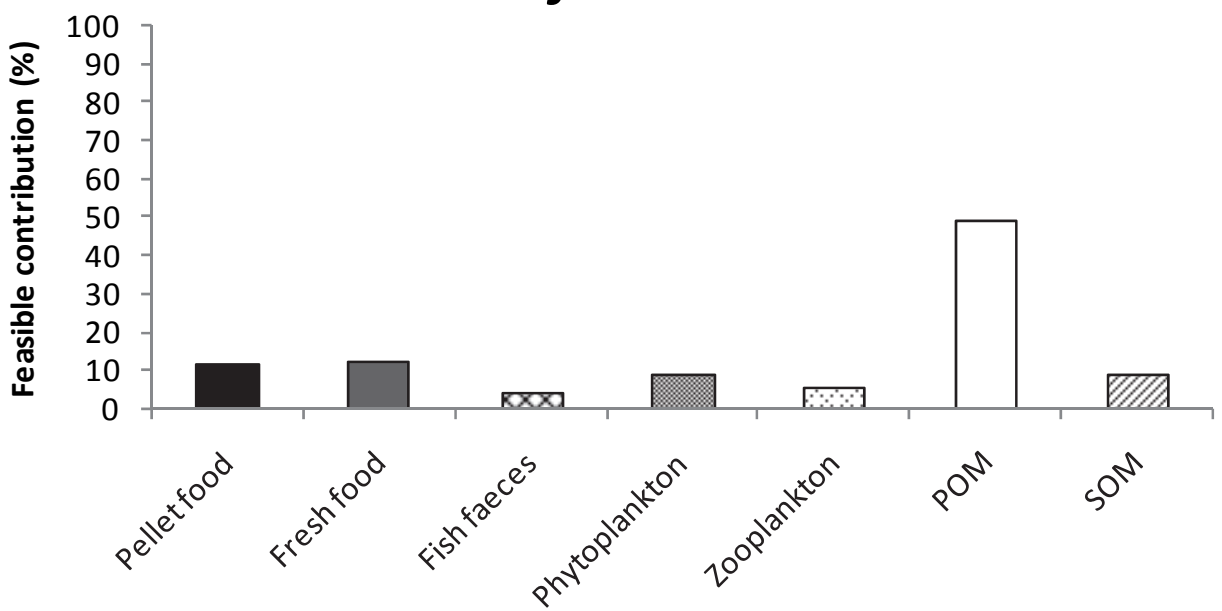

Fig. 12. Mean feasible contribution during the three years of study, of the main organic matter sources to the Holothuria forskalii isotopic signature, collected at the sea floor under fish cages and calculated by Bayesian mixing models.

\section{POM}

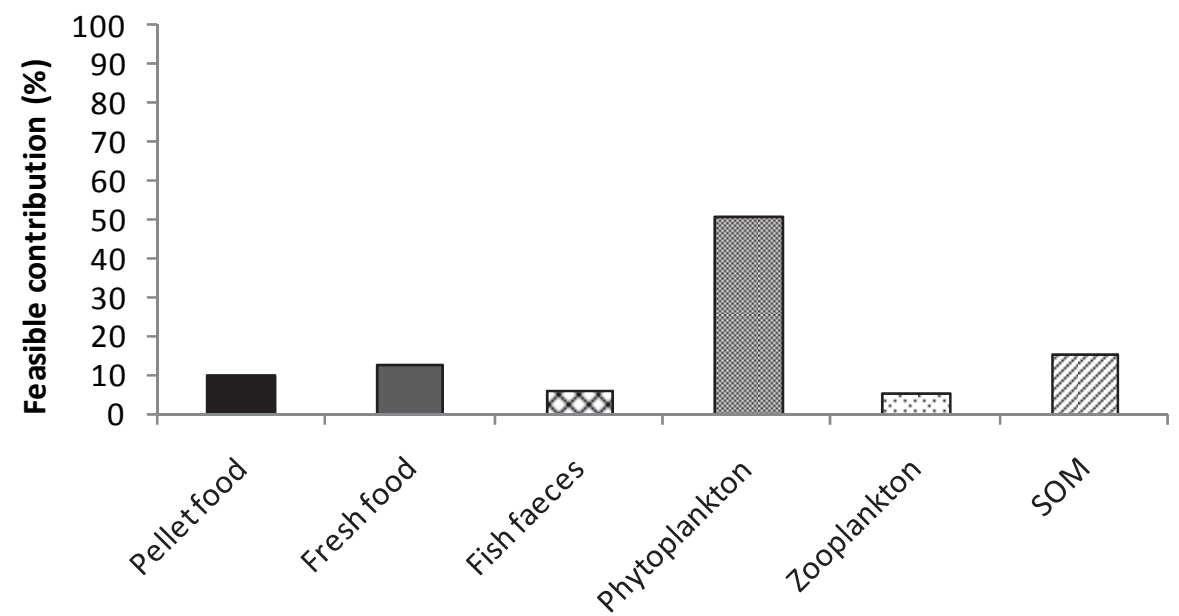

Fig. 13. Mean feasible contribution during the three years of study, of the main organic matter sources to the POM isotopic signatures collected at the sea floor, under fish cages, calculated by Bayesian mixing models. 


\section{Discussion}

The study is based on an approach of integrated multitrophic aquaculture to minimize the impact of aquaculture activities to the marine food web and benthic communities through stable isotope signatures of cultured Argyrosomus regius, filter feeder bivalves, aquaculture derived products, particulate and sedimentary organic matter at the proximity of cages. The results demonstrate the efficiency of integrated multitrophic aquaculture as valuable methods for the reduction of impacts of aquaculture activities at the coastal zone, especially so at oligotrophic waters such as the Balearic Islands.

Filter feeders bivalves (Mytilus galloprovincialis and Chlamys varia) are both enriched in ${ }^{13} \mathrm{C}$ and ${ }^{15} \mathrm{~N}$ at the cage treatment when compared to the bivalves studied at the two control sites. This clearly demonstrates that both bivalves are assimilating the aquaculture derived wastes in an efficient way precluding that future aquaculture installations should incorporate species with different feeding strategies (fish, filter feeders) in order to guarantee a good environmental status by improving water quality at fish farms.

\subsection{Food webs at cage and control treatments}

The food web quantified by stable isotope signatures at each treatment (cage and two control sites) depicted different matter fluxes. ${ }^{15} \mathrm{~N}$ isotopic signature can be used as a viable indicator to place trophic levels in a food web since nitrogen isotope 15 increases amongst trophic levels; therefore organisms higher in the trophic web will present higher $\delta^{15} \mathrm{~N}$ values. Accordingly, at the cage treatment the fish Argyrosomus regius has higher mean $\delta^{15} \mathrm{~N}$ values than filter feeders bivalves, zooplankton, phytoplankton, Holothuria forskalii, POM and SOM. Variability in $15 \mathrm{~N}$ isotopic signatures of pellet food reflects the pellet composition, which consists in a mixture of vegetal and fish meals with different proportion; pellet 2 is ${ }^{15} \mathrm{~N}$ enriched due to its composition with $78 \%$ fish meals and $22 \%$ vegetal meals, while pellet 1 is ${ }_{15} \mathrm{~N}$-depleted because it is mainly composed of vegetal meals, with $71 \%$. Previous studies have demonstrated that aquaculture derived waste enters the food web altering the natural isotopic composition of organic matter sources at the base and the upper trophic levels (Vizzini \& Mazzola, 2004) as it is the case for our results.

In the cage treatment filter feeders bivalves showed a nitrogen isotopic signature similar to that one for zooplankton, phytoplankton, fresh food, Argyrosomus regius faeces and Holothuria forskalii. This similarity demonstrates that filter feeders are working efficiently by getting their nitrogen isotopic signature from the filtered substances. Phytoplankton, Holothuria forskalii, POM and SOM are carbon enriched compared to the other samples.

Figure 3 and 4 follow the same structure as Figure 2. While in cage treatment, POM is carbon enriched compared to SOM, in control 1, it is the other way round, SOM has higher values of $\delta^{13} \mathrm{C}$ than POM. Nevertheless, filter feeders in control site 1 have nitrogen isotopic signatures higher than POM and SOM, which are in the lower part of the food chain, and isotopic signatures similar to those for zooplankton and phytoplankton. In Figure 3 we can observe how POM has $\delta^{13} \mathrm{C}$ values much lower than the POM sampled in the cage site and control 2 site. We can also observe that in control site 2 all ${ }^{15} \mathrm{~N}$ isotopic signature values for all samples are slightly lower than values found for samples in both cage site and control site 1 . In control site 2 we find cleaner waters which are purified as well as by filter feeders by aquatic plants such as Posidonia oceanica (Linnaeus) Delile 1813 
which are present in smaller amounts or not even present in the cage site and control site 1. Aquatic plants give up dissolved nitrogen in waters, meaning that there are smaller amounts in the aquatic mean available for filter feeders, phytoplankton and zooplankton, resulting in a decrease of the isotopic signature for these compared to the isotopic signature values given in the other two study sites.

Regarding the filter feeder bivalves, Mytilus galloprovincialis has lower $\delta^{15} \mathrm{~N}$ and $\delta^{13} \mathrm{C}$ values than Chlamys varia (Figures 5, 6, 7 and 8). Difference in $\delta^{13} \mathrm{C}$ between species are smaller than differences in $\delta^{15} \mathrm{~N}$, the reason being that nitrogen is more stable than carbon. Nitrogen is used in amino acids and lipids while carbon is used in carbohydrates which are constantly being used up. Nitrogen therefore has a longer persistence in tissues than carbon, showing up with a higher isotopic signature. Moreover, nitrogen-rich fish waste affects $\delta^{15} \mathrm{~N}$ values, while $\delta^{13} \mathrm{C}$ shows less variation as already stated by previous studies (Vizzini \& Mazzola, 2004).

For all study sites, SOM always gives lower $\delta^{15} \mathrm{~N}$ values and higher $\delta^{13} \mathrm{C}$ values in contrast to the other samples. Low values of SOM might be attributed to the fact that only the fine fraction of the sediment $(<125 \mathrm{~mm})$ was analysed for stable isotope determination. Another explanation could be a larger filtering capacity and high waste assimilation by filter feeders therefore less organic matter will be available for incorporation at SOM. Other studies (Sarà et al., 2004, 2006) have addressed effects of farming wastes to POM and SOM, but no inclusion of all organic sources and consumers have been considered. Our study improves knowledge on fish farms effects by integrating filter feeders bivalves.

The enrichment in ${ }^{15} \mathrm{~N}$ exhibited by Holothuria forskalii in the cage site is derived by the incorporation of part of aquaculture wastes that sink to the seafloor, as it has been suggested by the Bayesian mixing model, and observed by other authors, as Dolenec et al. (2007). Even though it has been demonstrated that filter feeders are efficient in the assimilation of part of these products, there is still a fraction which accumulates in the sediment affecting the $\delta^{15} \mathrm{~N}$ signature of the sedimentivorous feeders. This is also reflected in control 1, which is ${ }^{15} \mathrm{~N}$ enriched relative to control 2 , where ${ }^{15} \mathrm{~N}$ enrichment is probably due to the effect that the presence of cleaner waters and aquatic plant communities might have on sedimentivorous species.

Higher $\delta^{13} \mathrm{C}$ values for Chlamys varia and Mytilus galloprovincialis in the cage site compared to the reference sites are probably linked to higher water residence time in the inner bay where the fish farm is deployed, while control sites are at open areas. Therefore, phytoplankton blooms at cage are more probable resulting in an increase of the $\delta^{13} \mathrm{C}$ isotopic signature for both filter feeders.

\subsection{Partial wastes contributions}

The existing annual variability of feasible contribution of fresh food and pellet food to Argyrosomus regius's diet (Figure 9) most probably depends on the nutritional regime that fin fish have been fed on; that is if they have been given more or less fresh food in contrast to pellet food. For the three years of study, the feasible contribution of pellet food compared to fresh food is considerable higher. During 2008, Argyrosomus regius shows a much higher feasible contribution of fresh food than during the other two years. The reason being is attributed merely to distinctions in the feeding mode and not due to a change in the intake nutrient strategy of Argyrosomus regius. 
Filter feeders bivalves in our study, Mytilus galloprovincialis and Chamys varia, show both seasonal and annual variability (Figure 10 and 11). During autumn 2009 and 2010 Chlamys varia has a higher feasible contribution due to pellet food (Figure 7 ) but it filter less pellet food during summer (2008 and 2010), with the exception of summer 2009. Chlamys varia increases the feasible contribution due to phytoplankton during spring and summer, a reason might be that during this time of the year phytoplankton blooms increase their presence increasing at the same time their contribution to filtered matter by Chlamys varia. The feasible contribution of phytoplankton, fish faeces and POM is very small and rather similar for Chlamys varia during autumn 2009 and 2010. During autumn there is a lower phytoplankton activity and less particulate organic matter and therefore the contribution of these will be lower. Therefore, the seasonal variability of Chlamys varia might indirectly indicate the seasonal variability of phytoplankton, POM and faeces.

Filtering capacity and assimilation of the different components of the food web by filter feeders bivalves present a remarkable pattern as observed from the mixing models calculated at Mytilus galloprovincialis and Chlamys varia (Figure 10 and 11). For both species, the partial contribution are complementary, in the sense that when one specie increases the feasible contribution due to pellet food, the other specie decreases the contribution due to this type of food and vice versa. This could be interpreted as a competitive strategy between both species, possibly due to being in the same bags limited by water income and nutrient availability. Another feasible explanation is that their diets differ seasonally, and meanwhile one is relying on phytoplankton, the other can be assimilating more aquaculture derived wastes and vice versa.

The influence of excess feed in the isotopic signal of the particulate organic matter (POM) of the water column in the cages is indicative of the impact on the marine ecosystem. Similarly, the high contribution of the particulate organic matter and debris supply to the isotopic signal of Holothuria forskalii reinforce the impact on the benthos. Thus, it would be interesting in future studies to take into account, as components of the food web, sedimentivores (which may further reduce the organic load in the sediment), opportunistic fish species (which may alter the carbon fluxes and benthic and pelagic nitrogen) and the microbial loop (which rejoins the nutrients back to the food web, assuming a renewal of the carbon and nitrogen present).

\section{Acknowledgements}

This work was financially supported by the JACUMAR project (Ministerio de Medio Ambiente y Medio Rural y Marino). The authors thank several people involved in samples processing such us F. Fuster, S. Sardu and M. Ceglia. Special thanks for collaboration in stable isotope analyses offered by the SCTI (Scientific-Technical Services) from the Balearic Island's University and B. Martorell. We appreciate the collaboration of the staff members of the marine protected area of $S^{\prime}$ Arenal.

\section{References}

Bergamino, L.; Lercari, D. \& Defeo, O. (2011). Food web structure of sandy beaches: Temporal and spatial variation using stable isotope analysis. Estuarine, Coastal and Shelf Science, Vol. 91, No. 4, (March 2011), pp. 536-543, 02727714 
Brown, J. R.; Gowen, R. J. \& McLusky, D. S. (1987). The effect of salmon farming on the benthos of a Scottish sea loch. Journal of Experimental Marine Biology \& Ecology, Vol. 109, No. 1, (July 1987), pp. 39-51, 00220981

Carabel, S.; Godínez- Dominguez, E.; Verísimo, P.; Fernández, L. \& Freire, J. (2006). An assessment of sample processing methods for stable isotope analyses of marine food webs. Journal of Experimental Marine Biology and Ecology, Vol. 336, No. 2 (September 2006), pp. 254-61

Cheshuk, B.W.; Purser, G.J. \& Quintana, R. (2003). Integrated open-water mussel (Mytilus planulatus) and Atlantic salmon (Salmo salar) culture in Tasmania, Australia. Aquaculture, Vol. 218, No. 1-4, (March 2003), pp. 257-378, 00448486

DeNiro, M. J. \& Samuel, E. (1978). Influence of diet on the distribution of carbon isotopes in animals. Geochimica et Cosmochimica Acta, Vol. 42, No. 5 (May 1978), pp. 495-506

Dolenec, T.; Lojen, S.; Kniewald, G.; Dolenec, M. \& Rogan, N. (2007). Nitrogen stable isotope composition as a tracer of fish farming in invertebrates Aplysina aerophoba, Balanus perforatus and Anemonia sulcata in central Adriatic. Aquaculture, Vol. 262, No. 2-4, (February 2007), pp. 237-249, 00448486

FAO Yearbook. 2008. Fishery and Aquaculture Statistics. FAO, ISBN 978-9250066981, Rome, Italy

FAO. 2010. The state of world Fisheries and Aquaculture. FAO, ISBN 978-92-5-306675-9, Rome, Italy

Holmer, M.; Argyrou, M.; Dalsgaard, T.; Danovaro, R.; Diaz-Almela, E.; Duarte, C.; Frederiksen, M.; Grau, A.; Karakassis, I.; Marbá, N.; Mirto, S.; Pérez, M.; Pusceddu, A. \& Tsapakis, M. (2008). Effects of fish farm waste on Posidonia oceanica meadows: Synthesis and provision of monitoring and management tools. Marine Pollution Bulletin, Vol. 56, No. 9, (September 2008), pp. 1618-1629, 0025326X

Karakassis, I. \& Hatziyanni, E. (2000). Benthic disturbance due to fish farming analyzed under different levels of taxonomic resolution. Marine Ecology Progress Series, Vol. 203, (September 2000), pp. 247-253, 01718630

Mazzola, A. \& Sará, G. (2001).The effect of fish farming organic waste on food availability for bivalve molluscs (Gaeta Gulf, Central Tyrrhenian, Med): Stable carbon isotopic analysis. Aquaculture, Vol. 192, No. 2-4 (January 2001), pp. 361-79, 00448486

McCutchan, J.H.; Lewis, W. M.; Kendall, C. \& McGrath, C. C. (2003). Variation in trophic shift for stable isotope ratios of carbon, nitrogen, and sulfur. Oikos, Vol. 102, No. 2 (August 2003), pp. 378-90, 00301299

Mente, E.; Pierce, G. J.; Santos, M. B. \& Neofitou, C. (2006). Effect of feed and feeding in the culture of salmonids on the marine aquatic environment: A synthesis for European aquaculture. Aquaculture International, Vol. 14, No. 5 (October 2006), 499-522, 09676120

Michener, R. H \& Lajtha, K. 2007. Stable isotopes in ecology and environmental science. Wiley-Blackwell, ISBN 978-1-4051-2680-9.

Mirto, S.; Bianchelli, S.; Gambi, C.; Krzelj, M. K.; Pusceddu, A.; Mariaspina, S.; Holmer, M. \& Danovaro, R. (2010). Fish-farm impact on metazoan meiofauna in the 
Mediterranean Sea: analysis of regional vs. habitat effects. Marine Environmental Research, Vol. 69, No. 1, (February 2010), pp. 38-47, 01411136

Phillips, D. L. \& Gregg, J. W. (2001). Uncertainty in source partitioning using stable isotopes. Oecologia, Vol. 127, No.2 (July 2001), pp.171-179

Reid, G. K.; Liutkus, M.; Bennett, A.; Robinson, S. M. C. \& MacDonald, B. (2010). Absorption efficiency of blue mussels (Mytilus edulis and M. trossulus) feeding on Atlantic salmon (Salmo salar) feed and fecal particulates: Implications for integrated multi-trophic aquaculture. Aquaculture, Vol. 299, No. 1-4, (February 2010), pp. 165-169

Sarà, G.; Scilipoti, D.; Mazzola, A. \& Modica, A. (2004). Effects of fishing farming waste to sedimentary and particulate organic matter in a southern Mediterranean area (Gulf of Castellammare, Sicily): a multiple stable isotope study $\left(\delta^{15} \mathrm{~N}\right.$ and $\left.\delta^{13} \mathrm{C}\right)$. Aquaculture, Vol. 234, No. 1-4, (May 2004), pp. 199-213,

Sarà, G.; Scilipoti, D.; Milazzo, D. \& Modica, A; (2006). Use of stable isotopes to investigate dispersal of waste from fish farms as a function of hydrodynamics. Marine Ecology Progress Series, Vol. 313, (May 2006), pp. 261-270, 01718630

Shpigel, M. \& Blaylock, R. A.(1991). The Pacific oyster, Crassostrea gigas, as a biological filter for a marine fish aquaculture pond. Aquaculture, Vol. 92, No. 2-3, (1991), pp. 187197,00448486

Skalli, A.; Hidalgo, M. C.; Abellán, E.; Arizcun, M. \& Cardenete, G. (2004). Effects of the dietary protein/lipid ratio on growth and nutrient utilization in common dentex (Dentex dentex L.) at different growth stages. Aquaculture, Vol. 235, No. 1-4, (June 2004), pp. 1-11, 00448486

Soto, D.; Aguilar-Manjarrez, J.; Bermúdez, J.; Brugère, C.; Angel, D.; Bailey, C.; Black, K.; Edwards, P.; Costa-Pierce, B.; Chopin, T.; Deudero, S.; Freeman, S.; Hambrey, J.; Hishamunda, N.; Knowler, D.; Silvert, W.; Marba, N.; Mathe, S.; Norambuena, R.; Simard, F.; Tett, P.; Troell, M. \& Wainberg, A. (2008). Applying an ecosystem-based approach to aquaculture: principles, scales and some management measures. In: FAO Fisheries and Aquaculture Proceedings 11, FAO

Stirling, H. \& Okumus, I. (1995). Growth and production of mussels (Mytilus edulis) suspended at salmon cages and shellfish farms in two Scottish sea lochs. Aquaculture, Vol. 134, (July 2005), pp. 193-210

Taylor, B. E.; Jamieson, G. \& Carefoot, T. H. (1992). Mussel Culture in British-Columbia the Influence of Salmon Farms on Growth of Mytilus edulis. Aquaculture, Vol. 108, No. 1-2 (November 1992), pp. 51-66.

Troell, M.; Halling, C.; Neori, A.; Chopin, T.; Buschmann, A. H.; Kautsky, N. \& Yarish, C. (2003). Integrated mariculture: asking the right questions. Aquaculture, Vol. 226, No. 1-4, (October 2003), pp. 69-90, 00448486

Vizzini, S. \& Mazzola, A. (2004). Stable isotope evidence for the environmental impact of a land-based fish farm in the western Mediterranean. Marine Pollution Bulletin, Vol. 49, No. 1-2, (July 2004), pp. 61-70, 0025326X

Weston, D. (1991). Quantitative examination of macrobenthic community changes along an organic enrichment gradient. Marine Ecology Progress Series, Vol.61, (March 1990), pp.233-244 
Yokoyama, H.; Abo, K. \& Ishihi, Y. (2006). Quantifying aquaculture-derived organic matter in the sediment in and around a coastal fish farm using stable carbon and nitrogen isotopes ratio. Aquaculture, Vol. 254, No. 1-4, (April 2006), pp. 411-425, 00448486 


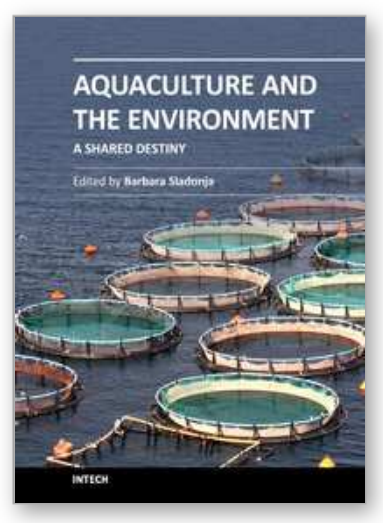

\author{
Aquaculture and the Environment - A Shared Destiny \\ Edited by Dr. Barbara Sladonja
}

ISBN 978-953-307-749-9

Hard cover, 246 pages

Publisher InTech

Published online 22, December, 2011

Published in print edition December, 2011

Aquaculture is the art, science and business of cultivating aquatic animals and plants in fresh or marine waters. It is the extension of fishing, resulted from the fact that harvests of wild sources of fish and other aquatic species cannot keep up with the increased demand of a growing human population. Expansion of aquaculture can result with less care for the environment. The first pre-requisite to sustainable aquaculture is clean wate, but bad management of aquatic species production can alter or even destroy existing wild habitat, increase local pollution levels or negatively impact local species. Aquatic managers are aware of this and together with scientists are looking for modern and more effective solutions to many issues regarding fish farming. This book presents recent research results on the interaction between aquaculture and environment, and includes several case studies all over the world with the aim of improving and performing sustainable aquaculture.

\title{
How to reference
}

In order to correctly reference this scholarly work, feel free to copy and paste the following:

Salud Deudero, Ariadna Tor, Carme Alomar, José Maria Valencia, Piluca Sarriera and Andreu Blanco (2011). Integrated Multitrophic Aquaculture: Filter Feeders Bivalves as Efficient Reducers of Wastes Derived from Coastal Aquaculture Assessed with Stable Isotope Analyses, Aquaculture and the Environment - A Shared Destiny, Dr. Barbara Sladonja (Ed.), ISBN: 978-953-307-749-9, InTech, Available from:

http://www.intechopen.com/books/aquaculture-and-the-environment-a-shared-destiny/integrated-multitrophicaquaculture-filter-feeders-bivalves-as-efficient-reducers-of-wastes-derived-

\section{INTECH}

open science | open minds

\section{InTech Europe}

University Campus STeP Ri

Slavka Krautzeka 83/A

51000 Rijeka, Croatia

Phone: +385 (51) 770447

Fax: +385 (51) 686166

www.intechopen.com

\section{InTech China}

Unit 405, Office Block, Hotel Equatorial Shanghai

No.65, Yan An Road (West), Shanghai, 200040, China 中国上海市延安西路65号上海国际贵都大饭店办公楼 405 单元

Phone: +86-21-62489820

Fax: $+86-21-62489821$ 
(C) 2011 The Author(s). Licensee IntechOpen. This is an open access article distributed under the terms of the Creative Commons Attribution 3.0 License, which permits unrestricted use, distribution, and reproduction in any medium, provided the original work is properly cited. 